\title{
Model of E-Leadership, Intra-team Communication and Job Satisfaction among School Leaders in Malaysia
}

\author{
Mohd Yusri Ibrahim,Phd \\ Centre for Fundamental \& Liberal Education, Universiti Malaysia Terengganu, Malaysia. \\ Email: yusri@umt.edu.my
}

\section{Doi:10.5901/mjss.2014.v5n23p1927}

\begin{abstract}
The study was conducted to develop a computer model of e-leadership based on mobile technology application, intra-team communication and job satisfaction among school leaders in Malaysia. Data was collected from 879 respondents through the online survey and analyzed using SEM. The finding shown that the e-leadership based on mobile technology is significantly contribute to the intra-team communication $(C R=7.235, \beta=0.301, P=0.00)$, while the intra-team communication is also positively predicted towards job satisfaction $(C R=8.448, \beta=0.356, P=0.00)$. The finding also shown the intra-team communication had fully-mediated to the relationship between e-leadership and job satisfaction. Finally, this study indicate that the model with intrateam communication as mediator was fit better $(x 2=321.286, x 2 / d f=2.869)$ than that the model without mediator $\left(\chi^{2}=471.817\right.$, $x 2 / d f=4.139)$.
\end{abstract}

Keywords: e-leadership; mobile technology; intra-team communication; job satisfaction

\section{Introduction}

Leadership is an important topic in organizational research throughout the years, including educational organization (Hallinger, 2011). Several studies by researcher had found that leadership styles affected organization from different perspective such as employee's attitudes and behaviors, which might also affect the feelings and thoughts of the employees (Cetin et al., 2012). Those studies also shown an effective organization usually lead by an effective leader (Horng \& Loeb, 2010).

Traditional or conventional leadership was define as using interpersonal influence and face to face communication in situations to attain specialized goals (Tannenbaum, Weschler and Massarik, 1959). However, latest world experienced a very rapid development in the field of communication and information technology ( Hambley et al. in Kock, 2009; Cascio \& Shurygailo, 2003). It enables work at any place and any time (Huang et. Al, 2010). These developments give new dimension in leadership and organizational management (Purvanova \& Bono, 2009; Avolio \& Kahai, 2002;2003, Avolio et al., 2001; DeSanctis \& Poole, 1994). Leadership role is no longer limited to a direct relationship between the leaders and members of the organization. Leaders can exercise their leadership in virtual function (Purvanova \& Bono, 2009).

As rapidly developmental in information and communication technology, leadership functions also grew by modernity and it always important part for organization (Schultz, 2010). Technology had changed the traditional approach of leadership to virtual concept. Virtual leadership or e-leadership is a concept that integrated mobile technology in leadership style, and it was different from traditional or conventional styles (Lee, 2010). E-leadership was define as a leader use computer mediating for task-oriented, decision-making and problem solving group (Hinds \& Kiesler, 2002).

As the development of mobile technology rises, most of leaders prefer in using mobile technology devices to coordinate their members in an organization. This may increase productivity by reducing operational cost (Huang et. al, 2010; Townsend et al, 2001). Although some research on virtual team leadership styles exists, relatively little research on how leadership affects virtual team interaction and performance (Hambley et al. in Kock, 2009). This study was conducted to investigate the contribution of e-leadership to group communication and job satisfaction among school leaders in Malaysia.

\section{Problem Statement}

Leader of modern organization faces more frequently due to the dynamics of the workplace and situation. The new challenges were workers are physically dispersed away from the leader and fellow (Schultz, 2010). In the Malaysian 
context, school leaders are very busy commonly. They rarely be able to attend school session for a variety of meetings and another commitments outside school (Mohd Yusri, 2012; Bity Salwana et. al, 2008; Maimunah, 2005) . As a result, they are not be able to pay attention to school organization, especially in part of curriculum and instruction (Mohd Suhaimi \& Zaidatol Akmaliah, 2007; Azlin, 2006).

To overcome this problem, the scholars have proposed the using of mobile technology in leadership. In this situation, leaders need to change their role as e-leaders in organization. The concept of e-leadership had suggested to elaborate how communication technologies can interact with group leaders and members in order to develop new team structures and cultures (Purvanova \& Bono, 2009; Avolio \& Kahai, 2002;2003, Avolio et al., 2001; DeSanctis \& Poole, 1994). Although some research on virtual team leadership styles exists, there is relatively little research on how leadership affects virtual team interaction and satisfaction on job performance (Hambley et al. in Kock, 2009).

\section{Purpose of the Study}

The purpose of the study was to develop a computer model of e-leadership, intra-team communication and job satisfaction among school leaders in Malaysia. The proposed model is based on the theory of three levels of product attributes, consequences and personal values. The theory suggests attributes of technology, consequences of value and personal attributes are hierarchically interconnected (McManus et al, 2009). From the theory and literatures (Purnova \& Bono, 2009; Avolio \& Kahai, 2003; Bell \& Kozlowski, 2002), the follows hypothesis model was proposed.

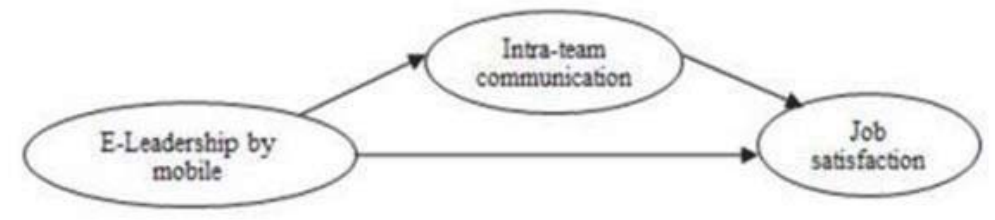

Fig. 1. Hypothesis model

\section{Research Methods}

The study was applied a cross sectional survey design using quantitative methods. The research population were school leaders in Malaysian that consists of principals, headmasters, senior assistant and head of the departments. Data was collected by questionnaire that was developed by the researcher. The instrument consists of three main part to measure the research variables namely e-leadership, intra-team communication and job satisfaction. A total of 879 respondents have answered the online questionnaire.

Data were analyzed using Structural Equation Modeling (SEM). Research questions were tested using regression coefficients and the critical ratio (CR). If the value of CR greater than 1.96 and significant values (P) of about 0.05 or smaller, it shows a predictor variables contributed significantly to the responsive variable. Fully-mediated and partialmediated methods were used to test the effects of mediator to the relationship between independent variable and the dependent variable. For the fully-mediated method, model without mediator was analyzed first, then followed by the model with mediators. If the value of khi square $(x 2)$ in model with mediator is smaller, then it proves that the mediator variables affect the relationship between the predictor and the criterion variables (Marsh et al, 1988; Browne and Cudek, 1993; Anderson and Gerbing, 1988). For partial-mediated method, indirect effect value was compared with the total effect value. If the indirect effect is smaller or equal to the total effect, it means the mediator variable affect the relationship between the predictor and the criterion variables (Shrout and Bolger, 2002; Mckinnon et al, 1995; Mckinnon and Dwyer, 1993).

The fit of model were tested using several fit indices such as $X 2$ (CMIN), GFI, CFI, RMSEA, PNFI and PCFI. The hypothesis model was considered fit to the collected data when the signifant value of X2 exceeding 0.05 (Chua, 2009; Meyers et. Al, 2006). Hypothesized model is also considered fit when the GFI exceeding 0.90 (Chua, 2009; Meyers et. Al, 2006). RMSEA value also considered very good if smaller than 0:08, but still acceptable if less than 0.1 (Byrne, 1998). Knight et al (1998) also suggests that acceptable CFI value is more than 0.90. But according to them, the CFI between 0.80 to 0.89 is still in the acceptable margin. The model also considered fit when PCFI and PNFI value exceeds 0.5 (Meyers et al. Al, 2006; Muliak et. Al, 1989). 


\section{Findings}

The testing model was conducted twice. The first, without the mediators, while the second using the intra-team as mediator between e-leadership and job satisfaction. The following Diagram 2 shows the results.

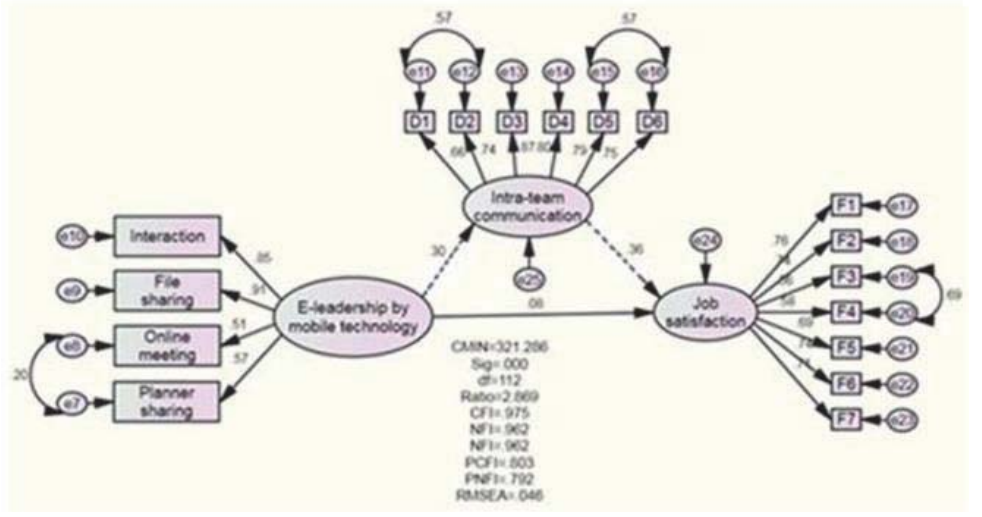

Fig. 2. Final model

The findings in Table 1 shown that e-leadership contribute positively to intra-team communication $(C R=7.235, P=.000)$ but did not contribute directly to job satisfaction ( $C R=1.933, P=.053)$. While intra-team communication contributed positively to job satisfaction $(C R=8.448, P=.000)$.

Table 1. Regression weights

\begin{tabular}{|c|c|c|c|c|c|c|c|}
\hline & & & Estimate & S.E. & C.R. & $P$ & Label \\
\hline Intra-team communication & $<--$ & E-leadership & .410 & .057 & 7.235 & $\star \star \star ~$ & par_12 \\
\hline Job satisfaction & $<--$ & Intra-team communication & .332 & .039 & 8.448 & *** & par_13 \\
\hline Job satisfaction & $<--$ & E-leadership & .096 & .050 & 1.933 & .053 & par_14 \\
\hline Planner sharing & $<--$ & E-leadership & 1.000 & & & & \\
\hline Online meeting & $<--$ & E-leadership & .472 & .034 & 13.857 & $\star \star \star ~$ & par_1 \\
\hline File sharing & $<---$ & E-leadership & 1.260 & .075 & 16.881 & *** & par_2 \\
\hline Interaction & $<--$ & E-leadership & 1.262 & .073 & 17.236 & 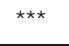 & par_3 \\
\hline
\end{tabular}

The result also found that the intra-team communication was partial-mediated the relationship between e-leadership and job satisfaction. The indirect effect $(0.136)$ is smaller than the total effect $(0.232)$. Therefore it can be conclude that intrateam communication mediated the relationship between the two variables.

Table 2. Total, direct and indirect effect

\begin{tabular}{llcccccccc}
\hline & \multicolumn{3}{c}{ Total effect } & \multicolumn{3}{c}{ Direct effect } & \multicolumn{3}{c}{ Indirect effect } \\
\hline & E-leadership & 1 & 2 & E-leadership & 1 & 2 & E-leadership & 1 & 2 \\
\hline 1 & Intra-team communication & .410 & .000 & .000 & .410 & .000 .000 & .000 & .000 .000 \\
2 & Job satisfaction & .232 & .332 & .000 & .096 & .332 .000 & .136 & .000 .000 \\
\hline
\end{tabular}

The findings also indicate that the model with the intra-team communication as mediator was better fit to the data than the model without mediator. Generally, all the tested index such as X2 (CMIN), CFI, RMSEA, PNFI and PCFI show the model with mediator was better. Table 3 below shows a comparison between the model with the mediator and the model without the mediator 
Table 3. Comparison model

\begin{tabular}{cccc}
\hline Fit index & Without mediator & With mediator & Requirement \\
\hline$X^{2}$ & 471.817 & 321.286 & Smaller is better \\
$\mathrm{df}$ & 112 & 112 & - \\
$\mathrm{X}^{2} \mathrm{df}$ & 4.139 & 2.869 & $<5$ \\
$\mathrm{CFI}$ & .957 & .975 & $>.90$ \\
$\mathrm{RMSEA}$ & .060 & .046 & $<.08$ \\
$\mathrm{PCFI}$ & .802 & .803 & $>.50$ \\
$\mathrm{PNFI}$ & .791 & 0.792 & $>.50$ \\
\hline
\end{tabular}

From the finding, we can conclude that e-leadership was contribute significantly to the intra-team communication, while intra-team communication contribute significantly to job satisfaction among the school leaders in Malaysia. Although the e-leadership not directly contribute to job satisfaction, but it's contribute significantly by attending intra-team communication as mediator. Finally, the study successful develop a computer model of e-leadership among school leaders in Malaysia.

\section{Conclusion}

The main purpose of this study is to develop a model of e-leadership among school leaders in Malaysia. The result was successful developed a model of e-leadership, intra-team communication and job satisfaction in hierarchically interconnected. The result shows that e-leadership contributes positively to intra-team communication, while intra-team communication was positively contributed to job satisfaction. Therefore, the intra-team communication was mediated the relationship between the two variables.

The result was similar to the previous scholars (Purvanova \& Bono, 2009; Avolio \& Kahai, 2002;2003, Avolio et al., 2001; DeSanctis \& Poole, 1994) that suggested that virtual leadership can be practiced by leaders with communication technology applied, especially mobile technology. Even a virtual function, but the leadership behaviors is still contributing to the effectiveness of communication within the organization and their job satisfaction.

In conclusion, the school leaders proposed to fully utilize mobile technology to practice their leadership functions. By the technology, a leader can be work at any place and any time. They can give the order, information and sharing with the members within organization. It also can increase the effectiveness of intra-team communication and contribute to the job satisfaction.

\section{References}

Anderson, J.C \& Gerbing, D.W. (1988). Structural equation modelling in practice: A review and recommended two-step approach. Psychological Bulletin, 103, 411-423

Avolio, B. J., Kahai, S., \& Dodge, G. E. (2001). E-leadership: implications for theory, research, and practice. Leadership Quarterly, 11(4), 615-668.

Avolio, B. J., \& Kahai, S. S. (2002). Placing the "E" in e-leadership: Minor tweak or fundamental change. In S. E. Murphy \& R. E. Riggio (Eds.), The Future of Leadership Development (pp. 49-70). Mahwah, NJ: Lawrence Erlbaum Associates.

Avolio, B. J., \& Kahai, S. S. (2003). Adding the "E" to e-leadership: How it may impact your leadership. Organizational Dynamics, 31, 325-338.

Avolio, B. J., Kahai, S. S., \& Dodge, G. E. (2001). E-leadership: Implications for theory, research, and practice. Leadership Quarterly, 11, 615-668.

Azlin Norhaini Mansor. (2006). Amalan pengurusan pengetua sekolah menengah: Satu kajian kes. Phd thesis, UKM, not published.

Bell, B. S., \& Kozlowski, S. J. (2002). A typology of virtual teams: Implications for effective leadership. Group and Organizational Management, 21, 14-49.

Bity Salwana Alias, Ahmad Basri Yussof, Ramlee Mustapha \& Mohammed Sani Ibrahim. (2008). Kompetensi pengetua sekolah menengah Malaysia dalam bidang pengurusan kurikulum. Paper work of Seminar Nasional Pengurusan dan Kepimpinan Pendidikan ke-15 IAB, Genting Highland.

Brown, M.W., Cudek, R (1993). Alternative ways of assesing model fit in: Bollen, K,

Long, J.S., (eds), Testing structural equation models. Sage, Newbury Park, CA, page 136-162.

Byrne, B.M. 1998. Structural Equation Modeling with LISREL, PRELIS and SIMPLIS: Basic Concepts, Applications and Programming. Mahwah, New Jersey: Lawrence Erlbaum Associates.

Cascio, W. F., \& Shurygailo, S. (2003). E-leadership and virtual teams. Organizational Dynamics, 31(4), 362-376.

Chua Yan Piaw. 2009. Asas statistik penyelidikan: Analisis data skala ordinal dan skala nominal. Shah Alam : McGraw-Hill (M). 
DeSanctis, G., \& Poole, M. S. (1994). Capturing the complexity in advanced technology use: Adaptive Structuation Theory. Organization Science, 5, 121-147.

Hallinger, P. (2011). A Review of Three Decades of Doctoral Studies Using the Principal Instructional Management Rating Scale: A Lens on Methodological Progress in Educational Leadership. Educational Administration Quarterly, 47(2), 271-306.

Hinds, P.J \& Kiesler, S. (2002). Distributed work; New Research in working across distance using technology. Cambridge: MIT Press

Horng, E. \& Loeb, S. (2010). New thinking about instructional leadership. Kappan, 92(3), 66-69.

Huang,R., Kahai, S. \& Jestice, R. (2010). The contingent effects of leadership on team collaboration in virtual team. Computers in Human Behavior 26: 1098-1110

Knight, G.P., Virdin, L.M., Ocampo, K.A \& Roosa, M.(1998). An examination of the cross-ethnic equivalence of measures of negative life events and mental health among Hispanic and Anglo-American children. American Journal of Community Psychology, 22(6), 767-783.

Kock, N. (2009). Virtual Team Leadership and Collaborative Engineering Advancements: Contemporary Issues and Implications. New York: Information science Refference

Lee, M.R. (2010). E-leadership for project managers: a study of situational leadership and virtual project success. Phd Disertation, Capella University

Maimunah Muda. (2005). Kepimpinan situasi di kalangan pengetua sekolah di Malaysia. Phd thesis, UKM, not published.

Marsh, H., Balla, J., McDonald, R. (1988). Goodness-of-fit indexes in conformatory factor analysis: The effect of sample size. Psychological Bulletine, 103, 391-410.

Meyers, L.S, Gamst, G \& Guarino, A.J. (2006). Aplied multivariate research: Design and interpretation. Sage Publication: London

Mohd Suhaimi Mohamed Ali \& Zaidatol Akmaliah Lope Pihie. (2007). Amalan kepimpinan pengajaran pengetua sekolah menengah luar bandar. Paper work of seminar pengurusan dan kepimpinan pendidikan ke-14 IAB, Genting Highland.

Mohd Yusri Ibrahim. (2012). Model kepemimpinan pengajaran, efikasi dan kompetensi pengajaran. Phd thesis, UMT, not published.

Morgeson, F. P. (2005). The external leadership of self-managing teams: intervening in the context of novel and disruptive events. Journal of Applied Psychology, 90(3), 497-508.

Muliak, S.A., James, L.R, Alstine, J.V, Bennet, N, Lind, S. \& Stilwell, C.D. (1989). Evaluation of goodness-of-fit indices for structural equation models. Psychological Bulletin, 105, 430-445

Purvanova, R.K \& Bono, J.E. (2009). Transformational leadership in context: Face-to-face and virtual teams. The Leadership Quarterly 20 (2009) 343-357

Schultz, R. W. (2010). Exploring leadership within the modern organization: Understanding the dynamics of effective leadership Of a virtual, multigenerational workforce. Phd Disertation, Capella University.

Tannebaum, R., Weschler, I. R., \& Massarik, F. (1959). Leadership and organization: A behavioral science approach. New York, NY: McGraw-Hill.

Townsend, A. M., Demarie, S. M., \& Henderickson, A. R. (2001). Desktop video conferencing in virtual workgroups: Anticipation, system evaluation and performance. Information Systems Journal, 11, 213-227.

Zaccaro, S. J., \& Klimoski, R. (2002). The interface of leadership and team processes. Group and Organization Management, 27,4-13. 